\title{
Playing God: An Essay on Law, Philosophy, and American Capital Punishment
}

Samuel J. Levine

Touro Law Center

Follow this and additional works at: https://digitalcommons.tourolaw.edu/scholarlyworks

Part of the Criminal Law Commons, and the Other Law Commons

\section{Recommended Citation}

31 N.M. L. Rev. 277 (2001)

This Article is brought to you for free and open access by the Faculty Scholarship at Digital Commons @ Touro Law Center. It has been accepted for inclusion in Scholarly Works by an authorized administrator of Digital Commons @ Touro Law Center. For more information, please contact Iross@tourolaw.edu. 


\title{
PLAYING GOD: AN ESSAY ON LAW, PHILOSOPHY, AND AMERICAN CAPITAL PUNISHMENT
}

\author{
SAMUEL J. LEVINE*
}

\section{INTRODUCTION}

As Professor Stephen Garvey has aptly described the process, the penalty phase in a capital case begins when a defendant has "pass[ed] the critical threshold of death-eligibility," a determination of which is subject to a number of constitutional limitations.' At that point, Garvey writes, the defendant "enters the individualized death-selection phase," in which the capital sentencer decides whether the defendant, already found to be eligible for the death penalty, should in fact receive this sentence. ${ }^{2}$ In stark contrast to the death-eligibility stage, Garvey identifies in the death-selection stage a "laissez-faire character." In particular, he notes that, consistent with the "individualization principle [that] governs this second stage," in deciding whether to impose the death penalty, a capital sentencer may consider almost any relevant mitigating or aggravating factor. ${ }^{4}$

On one level, the sheer quantity and range of factors that may be explored in the penalty stage of a capital case illustrate the broad responsibility and discretion entrusted to a capital sentencer. On a deeper and perhaps more significant level, however, the nature of a number of these factors reveals an anomalous and somewhat disturbing aspect of the capital sentencer's function in the legal system. Specifically, three of the factors implicate difficult philosophical and psychological issues that appear to require a capital sentencer to answer questions ordinarily thought of as insoluble through human reasoning.

In part through a comparison to principles of Jewish law and philosophy, ${ }^{5}$ this essay aims to show that many of the questions that the American capital sentencer is expected to answer can be resolved only on the basis of Divine knowledge. Part I of the essay discusses the unfair expectation that a capital sentencer will be able to resolve age-old questions of free will and moral luck and their relationship to criminal culpability. Part II identifies another troubling aspect of the capital

* Research Professor of Law, St. John's University School of Law; LL.M. 1996, Columbia University; Ordination 1996, Yeshiva University; J.D. 1994, Fordham University; B.A. 1990, Yeshiva University.

I thank Steve Garvey, Phyllis Crocker, and Sherman Clark for helpful conversations, and Fraida Liba and Yehudah Tzvi for their encouragement.

1. See Stephen P. Garvey, "As the Gentle Rain from Heaven": Mercy in Capital Sentencing, 81 CORNELL L. REV. 989, 1009-11 \& nn.74-81 (1996) (detailing constitutional limitations on categories of crimes that can lead to imposition of the death penalty).

2. Id. at 1011 .

3. See id.

4. See id. (citing Zant v. Stephens, 462 U.S. 862,877 (1983); Lockett v. Ohio, 438 U.S. 586, 604 (1978)). Indeed, Garvey cites the view that at this stage the sentencer is subject to "no substantive limitation at all." See id. (quoting Carol S. Steiker \& Jordan M. Steiker, Let God Sort Them Out? Refining the Individualization Requirement in Capital Sentencing, 102 YALE L.J. 835, 853 (1992) (Review Essay)).

5. Consistent with my approach elsewhere, rather than mechanically applying substantive conclusions in Jewish law regarding the place of capital punishment in the Jewish legal system, this essay instead "focuses on the conceptual underpinnings behind pertinent Jewish law [and philosophy], considering the potential relevance and effect of those conceptualizations on American legal thought." Samuel J. Levine, Capital Punishment in Jewish Law and Its Application to the American Legal System: A Conceptual Overview, 29 ST. MARY's L.J. 1037, 1039 (1998). See also Samuel J. Levine, Capital Punishment and Religious Arguments: An Intermediate Approach, 9 WM. \& MARY BนL RTS. J. 179 (2000). 
sentencer's decision: determination of a defendant's moral worth, ostensibly through an examination of every aspect of that person's life. Finally, part III critiques the assumption that the capital sentencer can predict with substantial accuracy the future dangerousness of a defendant. Thus, the essay argues that the American capital sentencer is asked to "play God," an expectation that, by its very nature, carries with it a daunting and unreasonable responsibility. ${ }^{6}$

\section{CULPABIITY, FREE WILL, AND MORAL LUCK}

According to the Supreme Court, and in the view of many scholars, one of the main factors that a capital sentencer should consider in deciding whether to impose the death penalty is the level of the defendant's culpability. As Professor Garvey has put it, "[t] he more culpable a capital defendant is for his conduct, the more deserving he is of death." Consistent with this understanding of the concept of culpability and its relationship to capital punishment, the Supreme Court has authorized a capital sentencer to take into account broad indicia of culpability or a lack thereof. The factors to be considered include "any aspect of a defendant's character... and any of the circumstances of the offense that the defendant proffers as a basis for a sentence less than death." In support of the Court's approach, Professor Louis Bilionis has explained that "[t]he Constitution permits only morally appropriate impositions of the death penalty; it requires in every case that the capital sentencer reliably determine that death is indeed the morally appropriate penalty." Indeed, in a number of cases the Court has expressly emphasized the need

6. For examples of commentators who have viewed the implementation of the death penalty as an exercise in "playing God" in a different sense, see, e.g., EUGENE B. BLOCK, WHEN MEN PLAY GOD: THE FALLACY OF CaPtTal PUnishment (1983); Steven Brill, An Innocent Man on Death Row, AM. LAW., Dec. 1983, at 1 ("Having read the trial record and having found new evidence, I am convinced that he is innocent and that the Knapp case should remind us that a legal system-even our best of all legal systems-is too plain mortal to play God with life and death."), cited in Hugo Adam Bedau \& Michael L. Radelet, Miscarriages of Justice in Potentially Capital Cases, 40 STAN. L. REV. 21, 30 n.40 (1987); Judith A. Hagley, The Lawyer's Bookshelf, N.Y.L.J., Jan. 5, 1996, at 2 ("Given human fallibility, should jurors be handed the death penalty and asked to play God?").

7. Garvey, supra note 1, at 1022. Garvey incorporates a definition of culpability as "the factors of intent, motive and circumstance that determine the extent to which the offender should be held accountable for an act." See id. at 1022 n.130 (quoting Andrew von Hirsch \& Nils Jarenborg, Gauging Criminal Harm: A Living Standard Analysis, 11 OXFoRd J. LEGAL. STUDIES 1, 1 (1990)).

8. Lockett v. Ohio, 438 U.S. 586, 604 (1978) (plurality opinion).

9. Louis D. Bilionis, Moral Appropriateness, Capital Punishment, and the Lockett Doctrine, 82 J. CRIM. L. \& CRIMINOLOGY 283, 288 (1991). See also Stephen P. Garvey, Death-Innocence and the Law of Habeas Corpus, 56 ALB. L. REV. 225, 233 (1992) ("[T]o do justice to a particular [capital] defendant requires that the punishment reflect his particular moral guilt. Every morally relevant feature of the offender and the offense is to be accounted for and weighed in the death-selection decision."); Laura S. Underkuffler, Agentic and Conscientic Decisions in Law: Death and Other Cases, 74 NOTRE DAME L. REV. 1713, 1724 (1999) ("Focus on the defendant 'as a "uniquely individual human being"' in deciding whether he should live or die is deeply rooted in another principle: that the selection of an individual for death is based upon the 'moral culpability' of that person.") (quoting Booth v. Maryland, 482 U.S. 496, 504 (1987) (internal citations omitted)). Cf. Carol Steiker \& Jordan Steiker, Defending Categorical Exemptions to the Death Penalty: Reflections on the ABA's Resolutions Concerning the Execution of Juveniles and Persons with Mental Retardation, 61 LAW \& CONTEMP. PROBS. 89. 102 (1998) ("[T] he requirement of individualized sentencing derives from a commitment to individual moral culpability... as the central inquiry in a constitutional scheme of capital punishment."); Steiker \& Steiker, supra note 4 , at 844-58. 
for an approach to capital punishment that fully incorporates principles of culpability and morality. ${ }^{10}$

The underlying rationale for this emphasis on culpability is the fundamental recognition that "death is different." According to Professor Bilionis, "[t]he eighth amendment requires a uniquely high degree of confidence in the moral appropriates of any death sentence imposed, for the death sentence-unlike any other judgment rendered in our criminal or civil courts-calls for an incomparably severe and uniquely irrevocable action."12 In the language of Justice Stevens, the death penalty represents "an expression of the community's outrage-its sense that an individual has lost his moral entitlement to live."13 Thus, "capital punishment rests on not a legal but an ethical judgment-an assessment of the [defendant's]... 'moral guilt." "14

As the Court "has not developed any well-defined theory of moral culpability"1s and has-properly, according to some ${ }^{16}$ - declined to delineate specific kinds of mitigating evidence, scholars, courts, and legislatures have suggested numerous categories of evidence that may be considered as both aggravating and mitigating

10. William J. Bowers \& Benjamin D. Steiner, Death by Default: An Empirical Demonstration of False and Forced Choices in Capital Sentencing, 77 TEx. L. REv. 605, 625 \& nn.95-101 (1999) (citing cases); Phyllis L. Crocker, Concepts of Culpability and Deathworthiness: Differentiating between Guilt and Punishment in Death Penalty Cases, 66 FordHAM L REv. 21, 36 n.65 (1997) (citing cases); Underkuffler, supra note 9, at 1724-25 (citing cases).

11. See, e.g., Harmelin v. Michigan, 501 U.S. 957, 995 (1991) ("Our cases creating and clarifying the 'individualized capital sentencing doctrine' have repeatedly suggested that there is no comparable requirement outside the capital context, because of the qualitative difference between death and all other penalties."). See also Harris v. Alabama, 513 U.S. 504, 516 n.1 (1995) (Stevens, J., dissenting) (citing Supreme Court cases confirming that "death is a fundamentally different kind of penalty"); Simmons v. South Carolina, 512 U.S. 154, 185 (1994) (identifying "death-is-different" jurisprudence); Spaziano v. Florida, 468 U.S. 447, 468 (1984) (Stevens, J., concurring in part and dissenting in part).

[E]very member of this Court has written or joined at least one opinion endorsing the proposition that because of its severity and irrevocability, the death penalty is qualitatively different from any other punishment, and hence must be accompanied by unique safeguards to ensure that it is a justified response to a given offense.

Id.; Woodson v. North Carolina, 428 U.S. 280, 303-04 (1976) ("[D]eath is a punishment different from all other sanctions in kind rather than degree.") (citations omitted). For scholarly treatmeat of the "death is different" doctrine, see, e.g., HUGO ADAM BUDAU, DEATH Is DIFFERENT. STUDIES IN THE MORALTY, LAW, AND POLITCS OF CAPITAL PUNISHMENT (1987); Sherty F. Colb, The Qualitative Dimension of Fourth Amendment "Reasonableness", 98 CoLUM. L. REV. 1642, 1674 (1998) ("The Supreme Court...has rested an entire jurisprudence of capital punishment on the premise that state killing is sui generis and that noncapital precedents sometimes provide insufficient protection when applied in the capital context. The Court has declared by way of justification that 'death is different." ); Garvey, supra note 9, at 233 ("Death is different, and doctrinally its distinctness is expressed by this attention to moral detail. Nothing of moral relevance must be disregarded or overlooked."); Note, The Rhetoric of Difference and the Legitimacy of Capital Punishment, 14 HARV. L. REV. 1599 (2001); Underkuffler, supra note 9, at 1729 (citing Supreme Court cases that describe uniqueness of death penalty and stating that "[a]s a result of this uniqueness, it is particularly critical that the correct decision in each case be made, and correctness requires that all factors, circumstances, and aspects of the case be heard and weighed, without hindrance, by the sentencer."). But see Carol S. Steiker \& Jordan M. Steiker, Sober Second Thoughts: Reflection on Two Decades of Constitutional Regulation of Capital Punishment, 109 HARV. L. REV. 355, 397 (1995) (finding that "[ $t]$ he Court echoed the 'death is different' principle in a number of...cases, but close examination of the Court's decisions over the past twenty years reveals that the procedural safeguards in death cases are not as different as one might suspect.").

12. See Bilionis, supra note 9 , at 318.

13. Spaziano, 468 U.S. at 469 (Stevens, J., concurring in part and dissenting in part).

14. Id. at 481 .

15. Garvey, supra note 1 , at 1023.

16. See Bilionis, supra note 9 , at 302 (suggesting virtues of Court's approach). 
factors to determine the moral culpability of a capital defendant. ${ }^{17}$ Notably, a number of the categories appear to implicate considerations and decisions that in various systems of moral and legal philosophy, including Jewish law, are thought to require powers of knowledge and judgment outside the range of human capability.

\section{A. Free Will Theories}

Garvey sets forth two categories of mitigation that relate the defendant's culpability to the degree to which the criminal act was a product of the defendant's free will: "will" or "choice" theory and "character-will" theory. ${ }^{18}$ As Garvey observes, both of these theories "forge a link between the offender's act and his free will," because, under both theories, "the measure of deserved punishment...depends on the choices the defendant has made."19

The first theory "holds an offender responsible for his act if and only if it was the product of his free will."20 Although this principle applies to criminal law more generally, ${ }^{21}$ Garvey explains its unique significance in capital cases. Unlike the general rule, which "shield[s] an offender from criminal liability only where his will has been almost completely overborne" due to conditions such as insanity, duress, and involuntary intoxication, a "defect in the [capital] defendant's will," though "less than total," serves to mitigate the severity of the punishment. ${ }^{22}$

The second theory, which Garvey calls the "character-will" theory, "locates responsibility not so much in the defendant's free will, but in his character."23 Having determined the nature of a defendant's character, he explains, the capital sentencer must decide whether the criminal act was "out of character."24 If so, similar to will theory, the facts or circumstances, if any, that caused the defendant to act this way may be mitigating factors. ${ }^{25}$ Alternatively, if the criminal act is consistent with the defendant's malevolent character, the question becomes "whether the defendant's character is the product of events beyond his control."26 Ultimately, Garvey observes, both theories "ground culpability in some conception of free will."27

Questions regarding free will and its relationship to criminal law take many forms and are not restricted to the context of capital punishment. ${ }^{28}$ In other types of criminal cases, though, notwithstanding the "millennia-old moral, religious, and

17. See, e.g., id. at 302-05 \& nn.60-82; Phyllis L. Crocker, Childhood Abuse and Adult Murder: Implications for the Death Penalty, 77 N.C. L. REV. 1143,1153 n.36 (1999).

18. See Garvey, supra note 1, at 1023.

19. Id. at 1026.

20. Id. at 1023 .

21. See, e.8., H.L.A. HART, PUNLSHMENT AND RESPONSIBIITY 152 (1968).

22. See Garvey, supra note 1, at 1023.

23. Id. at 1024.

24. See id.

25. See id.

26. Id. at 1025 .

27. See id. Cf. Kent Greenawalt, Punishment, 74 J. CRMM. L. \& CRDMnology 343, 348 (1983) (stating that "acceptance of free will...is certainly the undergirding for the ordinary sense of morality").

28. For a long list of works discussing issues of free will, see Sherman J. Clark, The Courage of Our Convictions, 97 MICH. L. REv. 2381, 2402 n. 39 (1999). 
philosophical debate over free will,"29 "American criminal law is normally committed to the presumption that all criminal acts are voluntary, regardless of the circumstances in which they were committed." 30 As one court put it, "an individual determined to be 'sane' within the traditional constructs of the criminal law is held accountable for his actions, regardless of his particular disabilities, weaknesses, poverty, religious beliefs, social deprivation or educational background." 31

Though different courts ${ }^{32}$ and theorists have offered a wide range of rationales for this presumption, they generally recognize that, ultimately, "the problem [of free will and determinism] remains, and is likely to remain for the foreseeable future, unresolved." 33 Nevertheless, as a convention, "[t]he law treats man's conduct as autonomous and self-willed, not because it is, but because it is desirable to proceed as if it were. ${ }^{\text {"34 }}$ As one scholar has put it, "[t]he criminal law thus finesses the vexed

29. Id. at 2402.

30. Kevin Jon Heller, Beyond the Reasonable Man? A Sympathetic but Critical Assessment of the Use of Subjective Standards of Reasonableness in Self-Defense and Provocation Cases, 26 AM. J. CRM. L. 1, 13 (1998); id. at 13 n.54 (citing sources to support this proposition). punishment: Professor Kent Greenawalt explains the centrality of this presumption in the retributive theory of

If all of our acts are consequences of preceding causes over which we ultimately have no control, causes that were set in motion before we were born-if, in other words, philosophical determinism is true-then the thief or murderer is, in the last analysis, more a victim of misfortune than a villain on the cosmic stage. Although he may be evil in some sense and able to control his actions, his character has been formed by forces outside himself, and that ultimately determines the choices he makes.... Unless one wishes to take the paradoxical position...that people are guilty for qualities and acts they cannot help, the simple retributive theory is incompatible with determinism. It requires some notion of free will that attributes to humans responsibility for doing wrong in a way that is not atuributed to other animals.

Greenawalt, supra note 27, at 343.

31. Johnson v. State, 439 A.2d 542, 551 (Md. 1982). See also Steward Mach. Co. v. Davis, 301 U.S. 548 , 590 (1936) ("[T]he law has been guided by a robust common sense which assumes the freedom of the will as a working hypothesis in the solution of its problems.").

32. See e.g., Stewart v. Gramley, 74 F.3d 132 (7th Cir. 1996); State ex rel. D.D.H. v. Dostert, 269 S.E.2d 401 (W. Va. 1980); United States v. Brawner, 471 F.2d 969 (D.C. Cir. 1972); Blocker v. United States, 288 F.2d 853 (D.C. Cir. 1961); Cole v. State, 128 A.2d 437 (Md. 1957); State v. Macias, 131 P.2d 810 (Ariz. 1942); Orme v. Rogers, 260 P. 199 (Ariz. 1927).

33. Clark, supra note 28, at 2402-03. See also Meir Dan-Cohen, Responsibility and the Boundaries of the Self, 105 HARV. L. REV. 959, 960 n.l (1992) (stating "the free will problem is far from solved") (citing THOMAS NAGEL, THE VIEW FROM NOWHERE 1 10-37 (1986)); Heller, supra note 30, at 19 ("[T] he debate over free will and determinism [is] almost certainly unresolvable.").

34. Herbert L. PaCKer, The Lomits of the Criminal Sanction 74-75 (1968). See also Craig Haney, Psychological Secrecy and the Death Penalty: Observations on "The Mere Extinguishment of Life", 16 STUD. IN LAW, POLmincs \& SOC' Y 3, 29 (1997) ("In general, our criminal law embraces the fiction of free, unencumbered choice to facilitate the creation of a more easily managed system of responsibility.").

In a classic article, Judge David Bazelon observed that "[a]lthough it has been asserted repeatedly that only a free choice to do wrong will be punished, in practice the law presumes, almost irrefutably, that proscribed behavior is the product of a 'free agent confronted with a choice between doing right and wrong and choosing freely to do wrong." "See David L. Bazelon, The Morality of the Criminal Law, 49 S. CAL. L. REv. 385, 387 (1976) (quoting Roscoe Pound, Introduction to F. SAYRE, CASES ON CRIMINAL LAW at xuxvii (1927)).

For normative critiques of this position, see, e.g., Michael S. Moore, Causation and the Excuses, 73 CAL. L. REV. 1091, 1122 (1985) (arguing that "the law demands more than that we pretend people are free and thus hold them responsible as if they were. A just legal system requires people to be truly responsible."); $\mathbf{R}$. George Wright, The Progressive Logic of Criminal Responsibility and the Circumstances of the Most Deprived, 43 CATH. U. L. REv. 459, 495 (1994) ("There should be a natural uneasiness with the deployment of any admitted legal fiction for the sake of utility.").

Indeed, Judge Bazelon viewed the presumption of free will as an illustration of "the conflict between 
'intentionalism vs. determinism' debate."

The penalty phase of a capital case, which includes free will considerations, stands out as a significant exception to these general principles. ${ }^{36}$ This exception is an expression of the emphasis on moral culpability as a justification for imposing the most severe and irreversible of sentences. ${ }^{37}$ Regardless of the reason for the exception, however, it appears that the requirement that a capital sentencer arrive at a definitive moral judgment of the defendant, through a precise estimation of the extent to which the defendant acted out of free will, imposes upon the sentencer a burden beyond the capabilities of human beings. ${ }^{38}$ Such a decision requires qualities of knowledge and wisdom available only to an omniscient God. As Professor Kent Greenawalt has written, "[o]ne human can rarely judge with confidence the moral

certain moral pretenses and practices." See Bazelon, supra, at 389. Cf. David Luban, What's Pragmatic about Legal Pragmatism?, 18 CARDOZO L. REv. 43, 55 (1996).

The philosophical problem...is that once you admit one deterministic excuse, it becomes hard to exclude others.... However, no judge... has ever argued that because all behavior is caused no one should ever be convicted of a crime.... Instead, the legal system draws philosophically arbitrary lines that reflect little more than legislative and judicial hunches about who is responsible and who is not. This strategy...combines compatibilism (the view that determinism is compatible with responsibility) with conventionalism (the view that there is no such thing as responsibility apart from social conventions for ascribing it).

Id.

35. Heller, supra note 30, at 14. Cf. Peter Aranella, Convicting the Morally Blameless: Reassessing the Relationship Between Legal and Moral Accountability, 39 UCLA L. REv. 1511, 1611 (1992) (describing "determinism's constant threat to undermine liberal accounts of moral desert"); see also Jody Armour, Just Deserts: Narrative, Perspective, Choice, and Blame, 57 U. PIIT. L. REv. 525,538 (1996).

[D]eterminist doctrines like duress severely threaten the coherence and cogency of the intentionalist assumptions of ordinary criminal law discourse. Once we admit that decisions to break the law are sometimes blameless because those decision are determined by preceding factors, and once we acknowledge that in some cases we must inquire into the roots of bad intentions and choices to evaluate blameworthiness, we actually begin to wonder why we do not inquire into the roots of decision to break the law in all criminal cases.

Id. See also Bazelon, supra note 34, at 389 (quoting OUVER WENDELL HOLMES, THE COMMON LAW 45 (1881)).

[I] punishment "stood on the moral grounds which are proposed for it, the first thing to be considered would be those limitations in the capacity of choosing rightly which arise from abnormal instincts, want of education, lack of intelligence, and all other defects which are most marked in the criminal classes.

Id.

36. See Haney, supra note 34, at 30 ("Because of the unusually broad scope of capital penalty phases... they offer the potential to both contextualize the nature of choice and convey a richer and more compelling account of the causes of violent crime.").

37. As a federal judge has put it.

one area where a deterministic view of behavior would make a heavy impact is the death penalty. Society may be able to confine some individuals because they are a danger to society even if due to their genetic wiring their antisocial actions are not morally culpable. However, imposition of the death penalty is predicated on the moral culpability of the defendant.

Gilbert S. Merritt, From the Scopes Trial to the Human Genome Project: Where Is Biology Taking the Law?, 67 U. CIN. L. REV. 365, 375 (1999).

At least one scholar rejects the notion that the qualitative difference between death and other punishments serves as an adequate basis to explain "the courts' inconsistency in this regard." See Wright, supra note 34, at 492. Instead, he suggests, "it may be simply that we are more reluctant to tolerate judicial hypocrisy and illogic in condemning a defendant to death." Id.

38. In addition, as one empirical study found, "experts' explanations of human behavior that run contrary to notions of free will are hard to sell to the jury." See Scott E. Sundby. The Jury as Critic: An Empirical Look at How Capital Juries Perceive Expert and Lay Testimony, 83 VA. L. REV. 1109,1139 (1997). 
guilt of others." 39 This inability of humans to calculate with precision the moral guilt of others is of particular concern when the result of an error, if detrimental to the defendant, may result in an improper execution. ${ }^{40}$

\section{B. Victim Impact Evidence-Acceptance of Moral Luck}

In most death penalty states, another factor that a capital sentencer may consider during the penalty phase is evidence of the impact of the crime on the victim or on the victim's family. ${ }^{41}$ Though the view of the Supreme Court has changed over time with respect to victim impact evidence, under Payne v. Tennessee, current legal doctrine allows for the introduction of such evidence in the penalty phase of a capital case. ${ }^{42}$ Based on the premise that "victim impact evidence is evidence of harm the defendant could not have reasonably foreseen," Garvey argues that, in permitting victim impact as a factor in capital sentencing, the Court has concluded that "moral blameworthiness can depend upon unforeseen and unforeseeable harm." The Court's conclusion is controversial because, as Garvey explains, the Court's approach implicates the complex and perhaps insoluble philosophical question of "moral luck."

In Thomas Nagel's definition, the concept of moral luck describes an underlying assumption in some systems, including the American legal system, through which "a significant aspect of what someone does depends on factors beyond his control,

39. Greenawalt, supra note 27, at 348. Cf. Haney, supra note 34, at 29 (describing the "complicated questions of causality and blameworthiness that capital jurors must work through in choosing between life and death"); Steiker \& Steiker, supra note 11, at 433 (arguing that the Supreme Court has "create[d] a false aura of rationality, even science, around the necessarily moral task of deciding life or death"); Robert Weisberg, Deregulating Death, 1983 SUP. CT. REV. 305, 353 (describing the "inscrutability of the death judgment" and terming it "an existential moment of moral perception, neither right nor wrong"); id. at 393 (describing the "inevitably unsystematic, irreducibly personal moral elements of the choice to administer the death penalty").

40. In the Court's language, "[b]ecause the death penalty is unique 'in both its severity and its finality," we have recognized an acute need for reliability in capital sentencing proceedings." Monge v. Califomia, 524 U.S. 721, 732 (1998) (quoting Gardner v. Florida, 430 U.S. 349, 357 (1977)). For other expressions of the unique nature of the death penalty, see id. (citing cases); sources cited supra note 11 (supporting proposition that "death is different").

41. See Garvey, supra note 1, at 1018 \& n.108 (citing State v. Muhammad, 678 A.2d 164, $177-78$ (N.J. 1996)); Wayne A. Logan. Through the Past Darkly: A Survey of the Uses and Abuses of Victim Impact Evidence in Capital Trials, 41 ARI. L. REv. 143, 150 (1999) ('Today, at least thirty-two of the thirty-eight death penalty states, as well as the federal government, permit victim impact evidence in capital trials, on the basis of either judicial or legislative authority.").

42. See Payne v. Tennessee, 501 U.S. 808 (1991) (overruling South Carolina v. Gathers, 490 U.S. 805 (1989) \& Booth v. Maryland, 482 U.S. 496 (1987)); Stephen P. Garvey, The Emotional Economy of Capital Sentencing, 75 N.Y.U. L. REV. 26, 48 (2000).

In 1987, the Supreme Court decided Booth v. Maryland, holding that victim impact evidence has nothing to do with a capital defendant's moral culpability and thus had no business being introduced into a capital trial. Four years later, the Court decided Payne v. Tennessee, changing its mind and holding that a state could fairly conclude that a capital defendant's culpability does depend on the details of the victim's life and the impact of her death on the members of her family.

Id.

43. Garvey, supra note 1 , at 1019.

44. See id. at 1020 . For a compilation of sources discussing issues of moral luck, see Alan Strudler \& Eric W. Orts, Moral Principles in the Law of Insider Trading, 78 TEX. L. REV. 375,417 n.179 (1999). 
yet we continue to treat him in that respect as an object of moral judgement."45 Applying this concept to victim impact evidence, Garvey notes that distinguishing between capital defendants based on unforeseeable harm allows the severity of sentence to be dependent on "a matter of luck." 46 Therefore, he finds that the Court's acceptance of victim impact evidence "rejects th[e] immunity-from-luck principle," which stands for the proposition that "[a]s much as possible, punishment should be immune from luck's vagaries." ${ }^{\text {"47 }}$ Critics of the Court's approach have argued that permitting victim impact evidence in capital sentencing thus punishes defendants for factors for which they are not culpable. For example, in dissenting from the Court's approach in Payne, Justice Stevens wrote that "defendants will be sentenced arbitrarily to death on the basis of evidence that would not ordinarily be admissible because it is irrelevant to the defendants' moral culpability." 1979).

45. Thomas Nagel, Moral Luck, in ThOMas Nagel, MORTAl QUestions 26 (Cambridge University Press

In fact, Nagel delineates four categories of moral luck: (1) "constitutive luck," which refers to "the kind of person you are" by virtue of "inclinations, capacity, and temperament"; (2) "luck in one's circumstances," which includes "the kinds of problems and situations one faces"; (3) "luck in how one is determined by antecedent circumstances"; and (4) "luck in the way one's actions and projects turn out." See id. at 28.

Cf. Stephen J. Morse, Brain and Blame, 84 GEO. L.J. 527, 536-37 (1996).

All human action is, in part, the product of but-for causes over which agents have no control and which they are powerless to change, including their genetic endowments and the nature and context of their childrearing. If people had different genes, different parents, and different cultures, they would be different. Moreover, situational determinants over which agents have no control are but-for causes of much behavior. A victim in the wrong place at the wrong time is as much a but-for cause of the mugging as the mugger's genetics and experiences. If no victim were available, no mugging occurs, whatever the would-be mugger's intentions. Such considerations are treated by philosophers under the rubric, "moral luck." Our characters, and our opportunities are in large measure the product of luck, and if luck excused, no one would be responsible.

Id.; Stephen J. Morse, Crazy Reasons, 10 J. CONTEMP. Legal Issues 189, 208 (1999).

Thus, according to both Nagel and Morse, the concept of moral luck has considerable relevance to discussions of the death penalty, beyond its implications regarding the inclusion of victim impact evidence in capital sentencing. More generally, moral luck raises profound questions about many of the fundamental concepts of moral culpability involved in the administration of the death penalty, including issues of free will. See supra Part I.A.

46. See Garvey, supra note 1 , at 1020.

47. Id. See also Basil A. Umari, Note, Is Tort Law Indifferent to Moral Luck?, 78 TEX. L. REV. 467,469 (1999) ("Moral luck conflicts with our basic intuition that a person's moral culpability should not depend on events beyond that person's control."). But see David D. Friedman, Should the Characteristics of Victims and Criminals Count?: Payne v. Tennessee and Two Views of Efficient Punishment, 34 B.C. L. REv. 731,765 (1993) (finding that "punishment does, and... to most people it seems that punishment should, depend on factors unrelated to how wicked the crime shows the perpetrator to have been").

48. Payne v. Tennessee, 501 U.S. 808, 866 (1991) (Stevens, J., dissenting). See also Jeffrey L. Kirchmeier, Aggravating and Mitigating Factors: The Paradox of Today's Arbitrary and Mandatory Capital Punishment Scheme, 6 WM. \& MARY BIL RTS. J. 345, 385 (1998) (The murderer...often does not know the specific information about the victim, so such specific information is not relevant to the defendant's culpability."); Note, The Supreme Court: 1990 Term, Leading Cases, 105 HARV. L. Rev. 177, 177 (1991) (criticizing the Court in Payne for "eviscerat[ing] the fundamental principle that capital sentencing should focus solely on the individual culpability of the defendant"); id. at 181 (arguing that the Court "in no way demonstrated how the unforeseeable harm the defendant caused...illuminates his personal blameworthiness" and that "[t]hus, without explicitly disavowing the underlying premise of its previous capital sentencing jurisprudence, the Court unmistakably moved toward abandoning the notion that individual culpability alone should guide these decisions"). Cf. Kenneth W. Simons, When is Strict Criminal Liability Just?, 87 J. CRM. L. \& CRMmOLOGY 1075, 1110 (1997).

In its classic exposition, at least, the principle of moral luck asserts that equally culpable individuals can deserve different punishments in light of the difference they actually make in 
responded to this criticism by noting other situations in which American criminal law incorporates into sentencing schemes differences in outcome that are beyond defendants' control, such as the distinction between an attempted crime and a completed one. ${ }^{49}$ Judge Richard Posner has offered a similar depiction of criminal law's acceptance of moral luck. Judge Posner noted that "in a system of morality in which only intentions and behaviors, but not consequences, count, there is no moral distinction between dangerous conduct that causes harm and otherwise identical dangerous conduct that does not. The only difference is luck, not usually considered a moral attribute." 50 By contrast, in describing the American legal system, Judge Posner explained that “'moral luck,' as philosophers refer to distinctions in culpability that are based on consequences rather than intentions, is, rightly or wrongly, a pervasive characteristic of moral thought in our society, at least the moral thought that informs the criminal law." 51

Such justifications, however, offer only descriptions of American criminal law, not normative arguments for allowing the determination of a capital sentence based on circumstances beyond the control of a defendant. Indeed, Judge Posner is unwilling to decide on a normative level whether the law's acceptance of moral luck in criminal sentencing is "right or wrong." 52 Perhaps it can be reasoned, as these descriptions imply and as others have explicitly argued, "since fortuity pervades every aspect of our lives, the law must blind itself to fortuity, otherwise the whole legal enterprise is in danger of collapse." 53

the world. It is a principle of responsibility for actual harm. But that principle does not justify a form of constructive culpability, in which the difference an offender actually makes in the world is the trigger for conclusively treating an individual as if he possessed a higher level of culpability than he actually possessed.

Id. As Garvey has noted, there is a difference of opinions among scholars regarding whether "only intended harm is relevant to deserved punishment" or "actual harm is also relevant." See Garvey, supra note 1, at 1021 \& nn. 12425 (collecting sources).

49. See Payne, 501 U.S. at 819-20.

50. United States v. Martinez, 16 F.3d 202, 205-06 (7th Cir. 1994).

51. Id. at 206.

52. See id.

53. See Umari, supra note $\mathbf{4 7}$, at $\mathbf{4 7 0}$ (citing this view and describing similar view that "because chance limits our control over the consequences of our actions, it tends to undermine our responsibility-based legal system and therefore must be ignored to some extent for our legal system to survive"). See also Friedman, supra note 47, at 763-64.

On the face of it, the moral argument against basing punishment on actual consequences seems to apply to all crimes and punishments, not merely murder and execution. If punishment ought to be a function of how blameworthy the criminal is, then punishment should never be affected by factors that the criminal did not know about or could not control. That sounds persuasive, but it does not describe how our legal system actually works. Indeed, it probably does not describe how any legal system actually works... In a wide range of civil and criminal cases, the sanction visited upon an offender depends in part on things that have little or nothing to do with how bad a person he is.

Id.; Craig A. Stern, Crime, Moral Luck, and The Sermon on the Mount, 48 CATH. U. L. REV. 801,839 n.111 (1999) ("Michael S. Moore has demonstrated that a consistent application of the doctrine that moral luck is to be eliminated from moral judgments would remove all human responsibility. One's character, one's health, one's opportunity to act, one's ability to choose, all depend, at least in part, upon luck."). But see Eric Lotke, Reflection and the Limits of Liability: Necessary Blindness in the Legal System, 54 OHIO ST. L.J. 1425, 1433 (1993) (identifying and rejecting view that "[a]s a practical matter, people must be held legally liable - even if they are not responsible in a deep moral sense"). 
Yet, like the similar argument for the presumption of free will in the law, such an approach falls short with respect to capital punishment. If we are to take seriously the Court's insistence that a sentence of death must be morally justified based on the defendant's culpability ${ }^{54}$ pragmatic acceptance of moral luck, though perhaps useful in other areas of criminal law, should not play a role in capital sentencing. ${ }^{35}$ As Justice Stevens forcefully and eloquently declared in his dissent in Payne, "[t]he notion that the inability to produce an ideal system of justice...somehow justifies a rule that completely divorces some capital sentence determinations from moral culpability is incomprehensible to me."56

Like the question of free will and determinism, moral luck, in the words of Thomas Nagel, is a "problem about moral responsibility to which we possess no satisfactory solution." 57 Indeed, the problem of moral luck is so vexing because it involves wisdom beyond that available to humans, judgments possible only on a Divine level. Nevertheless, the Court's decision in Payne permits victim impact to affect the sentence of a capital defendant. Thus, once again, the Court's approach requires that a capital sentencer decide the fate of a defendant's life by considering factors implicating deep and insoluble moral and philosophical questions.

\section{Jewish Law and Philosophy on Free Will, Luck, and Moral Culpability}

Like other moral and legal philosophers, scholars of Jewish law and philosophy have long recognized and addressed complex questions regarding free will and luck and their relationship to moral culpability. ${ }^{58}$ Following in this tradition, a leading contemporary American scholar of Jewish law and philosophy, Rabbi Joseph Soloveitchik, offered an analysis that captures the emphasis in Jewish thought on God's unique ability to engage in true moral judgment of human beings.

At the outset, Rabbi Soloveitchik notes the fundamental principle in Jewish thought that human beings have free will. ${ }^{59}$ Nevertheless, he recognizes that " $[\mathrm{e}] \mathrm{ven}$ as we emphasize man's free will, we are also aware that so much of what happens in life is not of man's making." ${ }^{\circ 60}$ Similar to many moral and legal philosophers who express concern about the forces that affect a person's actions and their

54. See sources cited supra note 10.

55. Cf. Amold H. Loewy, Culpability, Dangerousness, and Harm: Balancing the Factors on Which Our Criminal Law is Predicated, 66 N.C. L. REV. 283, 288 (1988) ("To the extent that culpability ought to be the sole criterion in assessing criminality... harm should be irrelevant to criminality.").

56. Payne v. Tennessee, 501 U.S. 808, 866 (1991) (Stevens, J., dissenting).

57. Nagel, supra note 45, at 25. See also Garvey, supra note 1, at 1021 ("The problem of moral luck defies easy solution.... Insofar as victim impact evidence raises the problem of moral luck, no simple solution exists.").

58. See, e.8., discussions in 1 ELYYAHU DESSLER, MICHTAV M'ELYYAHU 111-20, 278-83 (Aryeh Carmell \& Alter Halpern eds., 1954); 4 EluYAHU DESSLER, MichtaV M'EluYAHU 93-120, 321-23 (Aryeh Carmell ed., 1983); 5 ELTYAHU DESSLER, MichtaV M'EITYAHU 351-58, 500 (editor's note) (Aryeh Carmell ed., 1997); 1 ARYEh Kaplan, The HaNDBoOK OF Jewish Thought ch. 3 (Maznaim Publishing 1979).

59. See Abraham R. Besdn, Reflections of the Rav: Lessons In Jewish Thought $\mathbf{4 0}$ (Ahva Co-op Press 1979) (adapted from lectures of Rabbi Joseph B. Soloveitchik); see also KAPLAN, supra note 58, at ch. 3 (describing this principle and citing sources); YrIZCHOK HUTNER, PACHAD YITZCHOK: PURIM 79.81 (6th ed., 1998).

60. BESDIN, supra note 59, at 41. See also JOSEPH B. SoloverTCHIK, FAMLY REDEEMED: ESSAYS ON FAMIIY RELATIONSHIPS 168-71 (David Shatz \& Joel B. Woloweisky eds., 2000) (discussing the "inner contradiction of the idea of free will"). 
consequences, Rabbi Soloveitchik enumerates a long list of factors that an individual, despite possessing free will, cannot control. He observes, for example, that a person

does not choose the family into which he is born and reared nor the society whose values will have such an impact upon him. He makes choices, yet major aspects of his life seem governed by capricious, chance events and circumstances beyond his control. He is a vulnerable creature whose serenity may suddenly be jarred by overpowering temptations, peculiar turns of events, unexpected political coups, an economic collapse, a terminal illness, or traumatic shocks. ${ }^{61}$

After elaborating on the "[i]mational events...the instability, uncertainty and vulnerability which characterize human life...the sudden turns of fortune, lurking dangers, the fickleness of life, ${ }^{, 62}$ Rabbi Soloveitchik explains the legal relevance of these realities. Significantly, though he acknowledges that these forces beyond a person's control may indicate a lower level of culpability for wrongdoing, Rabbi Soloveitchik does not suggest that these forces be considered in the human administration of justice. Rather, he emphasizes that these factors play a role in Divine justice, as only God can truly adjudicate moral culpability.

Specifically, he continues, on the plane of true moral culpability, it must be recognized that "[o]ne individual may be saintly because he was reared in noble surroundings; another succumbs to evil because his home background lacked moral instruction and inspiration.... [T]he difference in their environments has affected their personalities." ${ }^{63}$ Thus, in judging individuals, Rabbi Soloveitchik asks, "[s]hould all sinners, then, be deemed equally guilty? Is not much of man's waywardness due to his susceptibility to external pressures? He finds himself almost overwhelmed by situations not of his own making, and by chance circumstances which propel him in various directions. ${ }^{164}$

61. See BESDIN, supra note 59 , at 41 .

62. Id. at 45.

63. Id. at $45-46$.

64. Id. at 46. For similar expressions of concern by American legal scholars regarding the actions of capital defendants, see William S. Geimer, Law and Reality in the Capital Penalty Trial, 18 N.Y.U. REV. L. \& SoC. CHANGE 273, 295 (1990-91).

Capital defendants are rarely, if ever, solely accountable for their crimes, and certainly their accountability never reaches the point where society can justifiably require them to forfeit their lives. Precisely because capital defendants did not spring full blown onto the earth at the moment of their crimes...they cannot justly be killed as punishment.

Id. Gary Goodpaster, The Trial for Life: Effective Assistance of Counsel in Death Penalty Cases, 58 N.Y.U. L. REV. 299, 335-36 (1983).

[T] understandable in light of his past history and the unique circumstances affecting his formative development, that he is not solely responsible for what he is. Many child abusers, for example, were abused as children. The knowledge that a particular abuser suffered abuse as a child does not, of course, excuse the conduct, yet it makes the crime, inconceivable to many people, more understandable and evokes at least partial forgiveness. Counsel's demonstration that upbringing and other formative influences may have distorted the defendant's personality or led to his criminal behavior may spark in the sentencer the perspective or compassion conducive to mercy.

Id.: Craig Haney. The Social Context of Capital Murder: Social Histories and the Logic of Mitigation, 35 SANTA Clara L. REV. 547, 560-61 (1995). 
These considerations, according to Rabbi Soloveitchik, form the basis for the fundamental principle of teshuva, as "God forgives man's sinfulness precisely because $\mathrm{He}$ acknowledges human vulnerability to changing fortunes, pressing circumstances, and the intrusion of the unexpected." Indeed, "[i]t is because of this [vulnerability] that man can stand before the Heavenly Bar of Justice, hoping for compassion and forgiveness." ${ }^{.66}$ Thus, "[d]espite his free will and his accountability for his deeds, man enters his plea before the Almighty, claiming that he is not the author and designer of the worldly pressures that were too powerful for him. These subverting temptations were thrust upon him by [the] circumstances." 67 In the end, then, "the basis for a penitent's claim to forgiveness [is] that his moral directions were....influenced by forces beyond his control, that his sinning was not entirely a free and voluntary choice. ${ }^{.68}$ Nevertheless, this claim of reduced culpability is not brought before a human court of justice. Rabbi Soloveitchik emphasizes that "[o]nly the Almighty can evaluate the extent of human culpability in situations which are not entirely of man's making," as "[o]nly God knows to what extent a man was a free agent in making his decisions." 69

It is instructive, then, to appreciate the similarities and differences between the approach of Rabbi Soloveitchik and that of the Supreme Court with respect to limitations on free will and their place in the administration of justice. While both acknowledge that human beings are subject to overwhelming forces that affect their

Social histories... are not excuses, they are explanations. An explanation does not necessarily dictate an outcome....[b]ut no jury can render justice in the absence of an explanation. In each case, the goal is to place the defendant's life in a larger social context and, in the final analysis, to reach conclusions about how someone who has had certain life experiences, been treated in particular ways, and experienced certain kinds of psychologically-important events has been shaped and influenced by them.

Id:; Andrea D. Lyon, Defending the Death Penalty Case: What Makes Death Different?, 42 MERCER L. REV. 695, 703 (1991) (arguing that "mitigation begins with the onset of the [defendant's] life" because "[m] any [defendants'] problems start with things like fetal alcohol syndrome, head trauma at birth, or their mother's drug addiction during pregnancy").

65. BESDN, supra note 59, at 45. For further discussions of the fundamental principle of teshuva, see, e.g., 2 AR YEH KAPLAN, THE HANDBOOK OF JEWISH ThOUGHT ch. 15 (Abraham Sutton ed., 1992); Samuel J. Levine, Teshuva: A Look at Repentance, Forgiveness, and Atonement in Jewish Law and Philosophy and American Legal Thought, 27 FordhaM URB. L.J. 1677 (2000); PINCHAS D. PEL,, SOLOVETTCHIK ON REPENTANCE (1984); ADN STEINSALTZ, TESHUVA (Michael Swirsky ed. \& trans., 1996). Cf. Symposium: The Role of Forgiveness in the Law, 27 Fordham URB. L.J. 1351 (2000); Dennis M. Cariello, Forgiveness and the Criminal Law: Forgiveness Through Medicinal Punishment, 27 FordhaM URB. L.J. 1607 (2000); Stephen P. Garvey, Punishment as Atonement, 46 UCLA L. REv. 1801 (1999); David M. Lerman, Forgiveness in the Criminal Justice System: If It Belongs, Then Why Is It So Hard to Find?, 27 FORDHAM URB. L.J. 1663 (2000).

66. BESDIN, supra note 59, at 46. Rabbi Soloveitchik's focus on Divine mercy is evoked in Garvey's description of mercy in capital sentencing. See Garvey, supra note 1. Indeed, the title of Garvey's article is quoted from Shakespeare, who refers to mercy as "the gentle rain from heaven" and as "an attribute to God himself." See id. at 989 n.1 (quoting William Shakespeare, The Merchant of Venice, act 4, sc. 1).

67. BESDN, supra note 59, at 46.

68. Id. Cf. SOLOVETTCHIK, supra note 60, at 169-70.

No matter how free a man is if seen under the aspect of the original scheme of creation, in the course of time and history he gradually becomes the slave of circumstances, an obedient servant of his milieu. He loses his courage and forfeits the heroic capability of defying everything and everybody. Temptation is too strong, sin fascinates, unredeemed vulgar beauty attracts with an irresistible force.... In other words, we deal here with an antinomy...the thesis says: man is an Id. adult, free and independent. The antitheses states: man is a child, weak and helpless....

69. BESDN, supra note 59 , at 46. 
free will and thus reduce their culpability, Rabbi Soloveitchik insists that only God possesses the wisdom to judge all of the circumstances that impact on an individual's moral guilt; the Court, in contrast, places on the capital sentencer the humanly impossible burden of determining the precise level of a defendant's moral culpability. $^{70}$

Likewise, with respect to issues relating to the problem of moral luck, Rabbi Soloveitchik again emphasizes the centrality of acknowledging the nature of Divine Justice in the world, explaining that "[e]vents which we label as accident belong to a higher Divine order into which man has not been initiated...not decrees of fate, but rather reasons beyond our comprehension operate in such instances."71 Like issues of free will, humans cannot fully understand how to incorporate apparent luck into a system of justice based on moral culpability. "To God," however, "there are no accidents, though they often appear so to us."72

Indeed, the overwhelming role of apparent luck in human endeavors often leads to a sense of helplessness in philosophical and theological attempts to deal with the problem of apparent injustice on a Divine level..$^{73}$ Questions of why the wicked sometimes prosper and the righteous suffer have perplexed philosophers and troubled Jewish religious thinkers since ancient times. Though these questions figure most prominently in the book of $J o b,{ }^{74}$ numerous biblical passages express the bewilderment of wise and devout individuals who long to understand the justice in these situations. ${ }^{75}$ In fact, the Talmud interprets Moses' request that God "inform me please of Your ways"76 as a plea to understand Divine justice. ${ }^{77}$ Despite attempts throughout the ages to begin to answer these questions, ${ }^{78}$ in the words of one contemporary scholar of Jewish law, in the end, "God's justice is hidden.... Though

70. Cf, Cesare Beccaria, Of Crimes and Punishments, in ALI ESANDRO MANZONI. THE COLUMN OF INFAMY 64-65 (Kenelm Foster \& Jane Grigson trans., 1964) ("[W]hat insect will dare take the place of divine justice...? The gravity of sin depends upon the inscrutable wickedness of the heart. No finite being can know it without revelation. How then can it furnish a standard for the punishment of crimes?'), cited in Michael S. Moore, The Independent Moral Significance of Wrongdoing, 1994 J. CONTEMP. LEGAL. ISSUES 237, 252 a.56 (1994); Jeffrie G. Murphy, Does Kant Have a Theory of Punishment?, 87 CoLUM. L. REV. 509, 516-17 (1987) (proposing "a reasonably consistent...philosophical account of state punishment [that] emerges" from Kant's writings): Moral iniquity is a function of inner dispositions and acts of will rather than external actions. Not only should the state not be concerned with such inner matters, it is in fact impossible-for both metaphysical and epistemological reasons-for the state to base rational policy on such inner concerns.... Persons who advocate retributivist goals for punishment reveal serious character defects-specifically a hardness of heart and a lack of proper moral humility. Many of those who are law-abiding are so only through luck-e.g., accident of temperament or freedom from temptation-and self-knowledge on such matters should make one cautious about setting the goal that others get exactly what they deserve. This is an attempt to play God, and human beings should avoid such attempts. From the point of view of God, who alone can see into the inner heart, the infliction of just punishment is a categorical imperative; but from the human point of view it is merely hypothetical.

71. BESDIN, supra note 59 , at 48.

72. Id.

73. Cf. Lloyd L. Weinreb, Law as Order, 91 HARv. L. REV. 909, 949 (1978) (“Job, we are inclined to believe, was the victim not only of misfortune but—were it not for deference to divine majesty-also of injustice.").

74. See, e.8., Job 12:6.

75. See, e.8., Jeremiah 12:1; Malachi 3:15; Psalms 73:2-3, 12-14; Ecclesiastes 8:14.

76. Exodus 33:13.

77. See TALMUD BAVL, Berakhoth 7a; 4 DESSLER, supra note 58, at 100-01.

78. For a compilation of many of these answers, see 2 KAPLAN, supra note 65, at ch. 20. 
we can begin to understand some general rules regarding God's justice, the details are far beyond human understanding and everything ultimately is in the hands of God alone. We must only realize...that all is just...."79 It is in recognition of "God's absolute knowledge" that "none can question His judgment." 80 As Rabbi Soloveitchik put it, "[e]ssentially this is God's answer to Job, who sought to reconcile his painful plight with his faith in God's justice. There is no deterministic fate; all operates on a transcendental plane which is beyond the grasp of man's finite mind."

Again, the contrast to capital sentencing in the American legal system is striking. If a punishment is from God, human beings can acknowledge their inability to understand but their willingness ultimately to respect Divine justice administered by an omniscient God. In a human justice system, however, allowing a capital sentencer to consider victim impact evidence asks the sentencer to act with Divine wisdom. The judge or jury is expected to determine a just punishment by incorporating into its calculus factors beyond the control of the defendant. The capital sentencer is thus instructed to disregard the problem of moral luck and is advised to ignore the apparent injustice in punishment that may result. As if in possession of Divine knowledge, the capital sentencer thereby functions as an arbiter of the role of luck in human behavior and punishment. ${ }^{82}$

\section{CHARACTER EVIDENCE}

Another factor that the Supreme Court has deemed relevant to the determination of sentence for a capital defendant is "character evidence."83 According to Garvey, this factor relates to "the content of the defendant's character itself." Thus, he explains, "[t] he character theory requires a jury to make a direct assessment of the defendant's moral worth." "In other words, this factor "is concerned, as some might

79. Id. at 20:53 (citations omitted).

80. Id.

81. BESDIN, supra note 59 , at 48.

82. Cf. Friedman, supra note 47, at 766-67 (citing the argument that "punishment according to outcome... is the best that human beings can do, and God will take care of correcting the inevitable errors in both directions" and adding that:

[f]or those of us who are concerned with providing justice without divine assistance, however, the prudential argument still leaves a moral problem. Even if it is prudent to use selective punishment to provide selective deterrence, is it just to punish differently offenders who may be equally wicked, merely because one had the good luck to miss the intended target or to choose a less attractive victim?).

Stern, supra note 53, at 829-30 (distinguishing between the "perspective of God's government," which reflects the notion that "[a]s a matter of absolute morality, both [a murderer and an attempted murderer] may deserve the same punishment," and "the perspective of human government," which is based on "our limited knowledge").

83. See Garvey, supra note 1, at 1026 n.145 (citing Supreme Court cases enumerating various elements relating to a capital defendant's character). See also Scott W. Howe, Resolving the Conflict in Capital Cases: A Desert-Oriented Theory of Regulation, 26 GA. L. REV. 323, 351 n.111 (1992) (citing cases).

84. See Garvey, supra note 1 , at 1026.

85. See id. See also Howe, supra note 83, at 351 ("[E]vidence about the offender's background and character...need not bear on his volitional capacity at the time of the capital offense... [T] must extend to an evaluation of what we might call the offender's general 'moral merit' or 'general deserts."'); Steiker \& Steiker, supra note 4 , at 847. 
put it, with the state of the defendant's "soul." "moral worth" and "soul" reflects the extent to which this factor places upon a capital sentencer the obligation to "play God." As difficult and arguably impossible as it may be for humans to judge the moral culpability of a single act, the task is that much more unreasonable when it requires a moral judgment of the essence of another human being, taking into account everything that makes up the person's inner nature. ${ }^{87}$

It may be argued, however, that despite the difficulty inherent in judging moral character, consideration of "general moral merit ha[s] typically influenced sentencing judgments about the appropriate level of punishment." ${ }^{88}$ As one scholar observed, "the argument of character...bring[s] into the sentencing process all of that soft data upon which sentencing judges have relied for the last hundred years-the defendant's religion, his past employment, his relations with his spouse, his childhood history, whether he loves animals, and so forth."

Such an argument, like similar ones regarding the place of free will and moral luck in the general criminal law, fails to acknowledge sufficiently the fundamental difference between the death penalty and other punishments. The fact that the law generally allows sentencing decisions to be based in part on a rough estimation of a defendant's moral worth does not imply that such a precarious and necessarily imprecise enterprise should play a part in the decision of whether to impose a capital sentence, a decision that leaves no room for error.

As in the analysis of the role of free will and moral luck in capital punishment, a look at Jewish law and philosophy helps illustrate the extent to which judgment of an individual's inner character is possible only through Divine wisdom and knowledge beyond that possible on the human level. ${ }^{90} \mathrm{Like}$ his ideas relating to the

[C]onsideration of good character evidence can be retrospective and nonutilitarian. Evidence of positive character traits and past good works may reveal a defendant's "general desert" and contribute to a moral assessment of the defendant's entire life that includes, but is not limited to, the defendant's culpability for the crime. A jurisdiction might regard such a general Id. Additionally, assessment particularly appropriate where the sentencing decision could result in execution.

consideration of good character evidence can be forward-looking and consequentialist. Evidence of a defendant's special talents or close family ties may suggest the defendant's capacity to make continuing contributions to society. And evidence of a defendant's religious devotion and remorse for the crime may reflect a defendant's commitment to observe legal norms in the future. A jurisdiction guided by utilitarian considerations would undoubtedly regard these types of good character evidence as indispensable components of individualized sentencing.

Id.

86. Garvey, supra note 1, at 1026. See also Howe, supra note 83, at 351 ("In effect the sentencer may determine what punishment the offender deserves by judging his 'soul."').

87. Cf. Howe, supra note 83, at 351 ("The sentencer may evaluate the offender's deserts based on all of his life works.").

88. Id. at 352.

89. Richard G. SINGer, Just DESERTS: SENTENCING BASED ON EQUALTTY AND DESERT 70 (1979), cited in Howe, supra note 83, at 352 n.115.

90. Cf. Edward M. Wise, The Concept of Desert, 33 WAYNE L. REV. 1343, 1358 (1987).

[Q]uestions of pure moral entitlement are impossibly difficult to decide. They ultimately require - summing up the sole of a person's character and actions in a single overall assessment. There is no rational way for human judges to do this, to tote up and balance off all of a person's moral excellences and failings. Thus a secular court has no practical use for the total picture of his virtues and vices pertinent to the ideal moral appraisal of an offender's conduct. Desert in an 
mysteries of free will, luck, and culpability, Rabbi Soloveitchik offers valuable insights in discussing the impossibility of one person truly understanding the essence of another human being.

In the eloquent words of Rabbi Soloveitchik,

[M]an has an inner world.... Man's ontological essence, that is, the essence of his being, is not to be equated with his conduct or routine activities. There is a homo absconditus, a "hidden man" whom no one knows... a mystery which no one can unravel.... The uniqueness of man-persona expresses itself in the mysterium magnum which no one except God can penetrate. ${ }^{91}$

Indeed, it is striking that the very kind of judgment expected of a capital sentencer is that which, in Jewish thought, is reserved for God, Who determines who will live and who will die based on Divine examination and weighing of individual merit. ${ }^{92}$ Although the precise nature of this Divine judgment is, by definition, beyond human comprehension, it is clear from the Talmud and other sources of Jewish law that only God has the ability to evaluate an individual's true moral worth.

In describing the process through which God judges an individual, Maimonides, the great medieval legal codifier and philosopher, writes that God balances a person's merits against that person's wrongdoings. ${ }^{93}$ Significantly, Maimonides posits that God's calculus does not involve a mere tallying of the number of good deeds against the number of sins. ${ }^{94}$ Rather, he explains, an accurate measurement of an individual's moral worth requires a careful weighing of different actions, good and bad, in accordance with their moral gravity. ${ }^{95}$ Therefore, Maimonides emphasizes, only God possesses the knowledge and wisdom necessary to make such a precise, complex, and vital determination. .6

Thus, the expectation that a human capital sentencer can estimate with any measure of precision the level of a defendant's moral character is highly problematic on at least two grounds. First, "[a]s a practical matter, a system for proportioning sentences to desert cannot be taken to require limitless inquiry into an offender's character." 97 Only God can inquire into and evaluate every aspect of a person's character. Second, and more profoundly, as Maimonides and Rabbi Soloveitchik demonstrate, it is unrealistic and therefore unfair-both to the sentencer and to the defendant - to expect any person to have the ability to assign

\footnotetext{
earthly forum never corresponds exactly to pure moral desert. It must inevitably be a rough

Id. estimate of the ideal.

91. SOLOVERTCHIK, supra note 60 , at 21 .

92. See MAIMONIDES, Mishne TORAH [COdE OF LAW], Laws of Teshuva 3:2-3.

93. See id. at 2:2.

94. See id.

95. See id.

96. See id: Ymzchok Hutner, Pachad Ytrzchox: Rosh Hashana 136-38 (4th ed., 1997). Cf. Greenawalt, supra note 27, at 348 ("[A] penalty supposed to redress a moral imbalance should perhaps depend upon an offender's overall moral record and how good and bad fortunes of his life compare with that record; yet making such an evaluation with any accuracy is even more beyond human capacities than judging the moral guilt attaching to a particular act.").

97. Wise, supra note 90 , at 1358.
} 
an ultimate moral weight to different aspects of a defendant's character and then balance these factors to arrive at a final decision of life or death. ${ }^{98}$

\section{FUTURE DANGEROUSNESS}

Finally, perhaps more than any other factor relevant to the determination of a capital sentence, a consideration of a defendant's "future dangerousness" requires that a human capital sentencer "play God" by predicting future events. ${ }^{99}$ Nevertheless, in Jurek v. Texas, ${ }^{100}$ the Supreme Court upheld the practice of incorporating predictions of future dangerousness into a death penalty sentencing scheme. In addition, in Barefoot v. Estelle, ${ }^{101}$ the Court held that the prosecution may present a psychiatrist's testimony regarding a capital defendant's propensity for committing future crimes.

The Court's willingness to allow a capital sentencer to rely on such a speculative consideration has drawn widespread criticism, beginning with Justice Blackmun's dissenting opinion in Barefoot. Citing an amicus brief filed by the American Psychiatric Association, Justice Blackmun noted that "[t]he unreliability of psychiatric predications of long-term future dangerousness is by now an established fact within the profession," and that "[t]he APA's best estimate is that two out of three predictions of long-term future violence made by psychiatrists are wrong." 102 Justice Blackmun's concerns have been shared by, among others, judges, legal commentators, and mental health professionals. ${ }^{103}$

98. Cf. Friedman, supra note 47, at 769 (citing position that "reject[s] punishment by moral desert not because it is inappropriate but because it is inappropriate to human courts and should therefore be left to divine justice"); Greenawalt, supra note 27, at 349 ("Even if one believes that a just God would strike some such balance [in punishment], he may think that restoring the moral order is not an appropriate human purpose, limited as the state should be in its capacities to learn about events and to dispose of people's lives.").

99. Cf. Bruce Vincent, Prosecutors Shun Death Penalty Expert: Dr. Death's Demise?. LeG. TIMES, Jan. 1,1996 , at 4 ("[Dr. Grigson] testified... in capital cases approximately 150 times for the state and eight times for the defense....[M] any of Grigson's peers think the doctor is playing God. Psychiatry is an inexact science where predicting a patient's future behavior is a goal, not a skill, one doctor says.").

100. 428 U.S. 262 (1976).

101. 463 U.S. 880 (1983).

102. Id. at 920 (Blackmun, J. dissenting).

103. For examples of legal scholars who have criticized the Court's approach and have compiled numerous sources in support of this criticism, see, e.8., Bowers \& Steiner, supra note 10, at 667 \& n.240 ("Judging a person's likely future dangerousness is far from foolproof; indeed, those who have examined such assessments find that they are often unreliable because they are subject especially to 'false positives' or predictions of dangerousness that do not materialize."); Garvey, supra note 1, at 1031 \& n.167 ("Unfortunately, our power to predict future dangerousness seems on a par with our power to predict next month's weather. Study after study shows that longterm predictions of future dangerousness are more often wrong than right."); Steven G. Gey, Justice Scalia's Death Penaly, 20 FLA. ST. L. REV. 67, 118 \& n. 216 (1992) (observing that "[n]o jury has the power to ascertain with 100 percent certainty the future actions of the defendant" and referring to "the dubious scientific or predictive value of future dangerousness evidence"); Lynne N. Henderson, The Wrongs of Victim's Rights, 37 STAN. L. REV. 937, 973 a.183 (1985) ("Despite the Supreme Court's recent acceptance of the notion that psychiatrists can predict future dangerousness for the purposes of imposing the death penalty, the ability of anyone to predict future dangerousness with much accuracy is questionable."); Kirchmeier, supra note 48, at 370-72 \& nn. 177-84 ("The use of the 'future danger' aggravating factor as a tool for determining who receives the death penalty is highly suspect."); Douglas Mossman. The Psychiatrist and Execution Competency: Fording Murky Ethical Waters, 43 CASE W. RES. L. REV. 1, 3-4 \& n. 10 (stating that the Court's approach "has been roundly criticized in both medical and legal literature"); Irene Merker Rosenberg, Yale L. Rosenberg \& Bentzion S. Turin, Return of the Stubborn and Rebellious Son: An Independent Sequel on the Prediction of Future Criminality, 37 BRANDEIS L.J. 511, 519- 
Despite these objections, however, the Court once again defended a questionable and troubling position on capital sentencing through a comparison to other decisions made in the administration of criminal justice. The majority in Barefoot responded to the criticisms Justice Blackmun highlighted by quoting at length from Justice Stevens' plurality opinion in Jurek: "It is, of course, not easy to predict future behavior. The fact that such determination is difficult, however, does not mean that it cannot be done. Indeed, prediction of future criminal conduct is an essential element in many of the decisions rendered throughout our criminal justice system." ${ }^{104}$ Specifically, the Court pointed to such actions as the setting of bail, judicial determination of a sentence, and the decision of parole authorities. ${ }^{105}$ Relying on these examples, the Court concluded that a capital sentencer's role in predicting future dangerousness is "no different from the task performed countless times each day throughout the American system of criminal justice."106

Thus, the Court's approach again accepted an inherently imprecise determination by a capital sentencer based on the legal system's acceptance of a similar determination in other situations, betraying a continued unwillingness to acknowledge the fundamental difference between death and other sentences. Refusing to accept the Court's approach, Justice Blackmun retorted that "[i]n the present state of psychiatric knowledge, this is too much for me. One may accept this in a routine lawsuit for money damages, but when a person's life is at stake...a requirement of greater reliability should prevail."107

Likewise, many scholars have been disturbed by the Court's seemingly shallow attitude to the profound implications of taking the life of another human being. In a sharply worded critique, Professor Paul Gianelli commented on the Court's rationale that "[n]either petitioner nor the [APA] suggests that psychiatrists are always wrong with respect to future dangerousness, only most of the time."108 Gianelli found that "[g]iven the context, such a standard-'not always wrong'-shocks the conscience," 109 adding that "[o]ne suspects that the Justices would not choose a neurosurgeon on such a basis, nor even a podiatrist." 110

$21 \&$ nn. $43-48$ (1998-99) (stating that "[a]lthough measures for predicting and preventing future crime are very much in vogue, a substantial body of literature suggests that prophecy of this sort is a very speculative business" and criticizing the Supreme Court for "a lack of appreciation of the inherent difficulty of the task and the consequences of using inadequate methodologies to identify the dangerous predator").

But see Albert W. Alschuler, Preventive Pretrial Detention and the Failure of Interest-Balancing Approaches to Due Process, 85 MICH. L. REV. 510,539 (1986) (characterizing Justice Blackmun's dissent as "inaccurate or misleading in six significant respects" and stating that "[c]ontrary to the 'nearly universal" view of academic and professional communities, the available evidence does not support the claim that predictions of future criminality are inherently or even usually inaccurate").

104. Barefoot, 463 U.S. at 897 (quoting Jurek, 428 U.S. 274-75 (Stevens, J.)).

105. See id.

106. Id. (quoting Jurek, 428 U.S. at 276 (Stevens, J.)).

107. Barefoot, 463 U.S. at 916 (Blackmun, J., dissenting).

108. Id. at 901 . (1993).

109. Paul C. Giannelli, "Junk Science": The Criminal Cases, 84 J. CRMM. L. \& CRIMINOLOGY 105, 114

110. Id. Cf. Rosenberg, et al., supra note 103, at 581-82.

Although conceivably one might be willing to accept a gaping margin of error in false positives with respect to certain forms of state intervention, such as short-term civil commitment or denial of bail, should we be willing to tolerate it for life sentences of recidivists or with respect to the death penalty? 
Responding to a different aspect of the Court's reasoning, Professor Serena Stier has argued that the tradition of American criminal justice adjudication precludes the use of predictions of future dangerousness for capital sentencing. ${ }^{11}$ 'Stier posits that " $[w]$ hen it comes to applying the death sentence on the basis of such unreliable predictions of future dangerousness... we certainly need to have a thorough and thoughtful normative discussion about the rightness of what we are doing." 12 After noting that "[a]ny criminal justice system is likely to make some errors," Stier notes that "American criminal jurisprudence has traditionally taken the view...that when error occurs, it is better to let the guilty go free than to punish the innocent."113 Therefore, she concludes, "[i]t seems to be contrary to this tradition to put the costs of error in capital punishment cases on the heads of those who must die for our mistakes."

In the Jewish legal system, courts abide by a nearly universal rule that an individual cannot be punished based on a prediction of future dangerousness. ${ }^{115}$ In fact, this rule applies not only to human courts but to God as well; notwithstanding the utterly unique ability God possesses to know future events, including future wrongdoings, with certainty, God imposes Divine justice only on actions that have already been committed. ${ }^{116}$ The one apparent exception to this rule, the case of the "stubborn and rebellious son," demonstrates the extent to which future dangerousness is generally excluded from consideration in Jewish law.

This special case involves a son who is sentenced to death after engaging in a number of specific, Biblically enumerated, wrongful activities that evince a particularly definite propensity for future sins of a much greater magnitude. ${ }^{117}$ The Talmud states that, although none of the actions actually committed are themselves capital crimes, the sentence corresponds to future crimes that the son would ultimately have committed. ${ }^{118}$ Thus, in this one scenario, Jewish law apparently sanctions the imposition of capital punishment due to the defendant's future dangerousness. Nevertheless, this exceptional case probably proves the rule that

Id. at 583 ("[O]ur predictive ability is one for three-not bad for a batting average but somewhat more problematic for imprisonment and execution.").

111. See Serena Stier, Hybrids and Dangerousness, 82 Nw. U. L. REV. 52, 61 (1987).

112. Id.

113. Id.

114. Id. Cf. Rosenberg, et al., supra note 103, at $520-21$ (referring to the Court's "lack of appreciation of the inherent difficulty of the task and the consequences of using inadequate methodologies to identify the dangerous predator" and arguing that

in our constitutional system, primacy presumably should be given to individual liberty, and if mistakes in predicting future criminality are to be made-as they surely will be-they should be on the freedom side of the ledger, particularly when dealing with gross deprivations, such as long-term incarceration and capital punishment.)

115. See RASH, COMMENTARY ON THE TORAH 79 (Chaim Chavel ed., 1986) (commenting on Genesis 21:17). See generally Rosenberg, et al, supra note 103.

116. See 1 KAPLAN, supra note 58 at 2:47; 2 KAPLAN, supra note 65, at 20:8-20:9 (citing Job 11:11); id. at $21: 28$. God's knowledge of the future raises a number of profound philosophical questions, including a potential paradox between this foreknowledge and the principles of free will and Divine justice. See Avoth 3:15; SA' ADIAH GAON, EMUNOTH V'DEOTH 158-59 (Yoseph Kapach trans., 1993); MAMMONDES, supra note 92, Laws of Teshuva 5:5; Ra'avad, Commentary in MAMONIDES, supra; 1 KAPLAN, supra note 58, at ch. 3.

117. See Deuteronomy 21:18-21; TALMUD BAVU, Sanhedrin, ch.8; MAIMONIDES, supra note 92, Laws of Mamrim, ch. 7.

118. See Talmud Bavl, Sanhedrin $71 b$. 
such predictions generally play no part in the administration of justice in Jewish law. In fact, consistent with the rest of the Jewish legal system, this case presents an argument against using human predictions of future harm as a justification for the death penalty.

First, although the Talmud understands the punishment as a means to prevent future harm, this determination of future dangerousness is not subject to the unavoidable uncertainty that detracts from human predictions. Here, the Torah, which is the word of God, mandates that an individual who engages in such activities is subject to the death penalty. ${ }^{119}$ Thus, the punishment is proper only because, in this exceptional case, as a result of God's unique knowledge of the future, the prediction of future crimes-unlike those of psychiatrists or other humans-is infallible. The human court, therefore, does not engage in any prediction of future harm, but instead merely adjudicates the case in accordance with the procedure delineated through Divine Revelation. ${ }^{120}$ Second, as the Talmud notes, this case is sui generis in the extent to which human administration of justice is based on future events. ${ }^{121}$ Finally, the Talmud articulates numerous procedural safeguards that protected the defendant in this case to such a degree that, according to one opinion in the Talmud, there never was and never will be an actual case of an execution of a stubborn and rebellious son. ${ }^{122}$

Ultimately, then, the case of the stubborn and rebellious son demonstrates the degree to which Jewish law and philosophy preclude the imposition of punishment pursuant to an inevitably speculative human prediction that the defendant will engage in future wrongdoing. ${ }^{123}$ Even God, Who knows rather than predicts the future, rarely if ever administers a punishment based on future dangerousness. Thus, the Supreme Court's willingness to allow a fallible capital sentencer to impose the most severe and irreversible of penalties on this basis creates a genuinely anomalous situation: the Court appears to authorize human beings to "play God" with disturbing impunity, entitling them to undertake actions beyond those taken by God. ${ }^{124}$

119. See Deuteronomy 21:21.

120. See Maharal, GUR AR YeH (commenting on Rashi, supra note 115); ChaIm Shmulevitz, Sichoth Mussar 87 (1983). Cf. Bruce S. Ledewitz \& Scott Staples, 6 U. FlA. J.L. \& PuB. POL'Y 33, 42 (1993). The American death penalty debate is beset by the justice issue. American opponents of the death penalty do not, by and large, agree that murderers-or other wrongdoers-deserve to die. Nor is there a consensus in America about the standards of morality that would allow the death penalty question to be resolved. Proponents of the death penalty may have convinced a majority of voters that murderers deserve to die, but they cannot demonstrate this proposition by reasoning from generally accepted premises. The rabbis did not have this problem. The proper

Id. punishments for crime were set forth in God's Word.

121. See TALMUd BAVL, Sanhedrin 71 b. See also 2 NACHMANIDES, COMMENTARY ON THE TORAH 445-46

(Chaim Chavel ed., 1960) (commenting on Deuteronomy 21:18).

122. See Talmud BavL, Sanhedrin 71 b.

123. See generally Rosenberg, et al., supra note 103.

124. Cf. id. at 583-84.

[I] we cannot achieve God's omniscience, that is if we cannot achieve perfection, we should at least be less imperfect. And if one for three is the best that we can do given our present state

Id. of knowledge, perhaps it may be time for a time out in the prediction game. 


\section{CONCLUSION}

By virtually all accounts, capital punishment is fundamentally different from all other forms of punishment in the American legal system. ${ }^{125}$ As a result of the profound difference, "many would say that the severity of death, and the inevitability of decision-makers' human errors, should preclude the sentence of death altogether." 126 Although it has repeatedly acknowledged the unique nature of the death penalty and the corresponding need for unique substantive and procedural safeguards in capital cases, ${ }^{127}$ the Supreme Court has sanctioned a wide variety of capital sentencing schemes. One particularly striking element of the Court's jurisprudence has been a willingness to allow a capital sentencer to make determinations that require Divine wisdom and knowledge.

Professor Jefferson Powell has offered a cogent warning in describing the limitations of human justice:

Our power...is limited by our limited and narrow and fallen vision, as well as other external limitations to our abilities. We are called on to seek human justice to approximate divine justice, but were we tempted to think that we can close the gap altogether we would be starting out on a path that will mislead us. ${ }^{128}$

In formulating an approach to capital punishment that expects the human capital sentencer to "play God," the Supreme Court appears to have taken several steps down this dangerous path.

125. See supra note 11 .

126. Underkuffler, supra note 9, at 1729.

127. See supra note 11.

128. Maura Ryan, Conversation: On Powell's Theology, 72 NOTRE DAME L. Rev. 41, 69 (1996) (quoting Powell). Cf. Harold J. Berman, The Origins of Historical Jurisprudence: Coke, Selden, Hale, 103 Y ALE L.J. 1651, 1706 n.147 (1994) (quoting Maija Jansson, Matthew Hale on Judges and Judging, 9 J. LEG. HIST. 201, 207-08 (1988)) (internal quotation omitted) ("[T]he hand of divine justice in the way of His providence may reach in after time a guilty person, or of evidence to convict him, he may hereafter repent and amend; but the loss of the life of an innocent is irrecoverable in this world."); Bruce Ledewitz, Could the Death Penalty Be a Cruel Punishment?, 3 WIDENER J. PUB. L. 121, 155 (1993) ("[W]ithout God, the full range of human experience must be accounted for here, in this world. No ultimate, transcendent justice is possible in a secular universe. The death penalty fails to be just without God."); Irene Merker Rosenberg \& Yale L. Rosenberg, Guilt: Henry Friendly Meets the MaHaRal of Prague, 90 MICH. L. REV. 604, 624-25 (1991) ("[D]n our imperfect world there is only one kind of ascertainable guilt, and that is legal guilt. The search for more is nothing less than arrogance."). 
